\title{
MORE LIGHT?
}

\section{Some Remarks on the Function of a Roman Mortarium from the 'Princely' Grave in Poprad-Matejovce}

\author{
J U D Y T A R O D Z I Ń S K A - N O W A K
}

\begin{abstract}
The article discusses the presumed functions of the provincial Roman mortarium discovered in the 'princely' grave in Poprad-Matejovce. The vessel may have served as a container for some unspecified food, as a component of a feast accompanying a funeral ceremony, or it may have been used as a lamp. In both cases, the strong influence of Roman culture on the population of the southern zone of Barbaricum at the end of antiquity is evident.
\end{abstract}

Keywords: Slovakia, Spiš region, Roman Period, 'princely' grave, mortarium, funerary rite, romanisation.

\section{INTRODUCTION}

The 'princely' grave from Poprad-Matejovce (Poprad distr., Slovakia), dated to the early phase of the Migration Period, is undoubtedly one of the most spectacular archaeological discoveries made in Central Europe in this century. The find was made by chance at the foot of the High Tatra mountains, in the area covered by the Northern Carpathian group in the above-mentioned chronological section, from which no other sepulchral sites of the people of the mentioned unit are known so far. ${ }^{1}$ A lot of attention has already been paid in literature to the impressive construction of this tomb, consisting of two wooden chambers, as well as to traces of its reopening and robbery, which probably took place shortly after the funeral ceremony. Studies have also been undertaken on the surviving elements of its inventory, among which the numerous objects made of raw materials of organic origin deserve special attention (Lau 2013; 2017; Lau/Pieta 2010; 2017; Pieta 2009).

The furnishings of the 'princely' burial also included eight ceramic vessels, found between the walls of the inner and outer chambers of the tomb, in the vicinity of a bucket made of brass sheeting, a basket woven from bast containing, among other things, silver-plated iron scissors, and near a cluster of animal bones accompanied by an iron knife (Lau 2013, 17, 19; Lau/Pieta 2010, 350, fig. 8; 2017, 258, fig. 3; Pieta 2009, 116, fig. 14). Seven of the clay vessels mentioned derive from the local, i.e. barbarian cultural environment. These include a hemispherical, hand-made bowl of considerable size (with a spout diam. of ca. $37 \mathrm{~cm}$ ) and six small specimens that can be described as bowls or dishes. Three of them are hand-made, while another three were made using a potter's wheel. All the vessels show technological and stylistic features of the late Roman and early Migration Period, i.e. phases C3-D, in the area of the Przeworsk culture, south-western Slovakia and Moravia, as well as in the Chernyakov culture. By far the greatest number of stylistic references to the above-mentioned examples can be found among the ceramic inventories of the Przeworsk culture (Rodzińska-Nowak, forecoming). Thus, the existence of influences coming from these directions, which have long been noticed in the studies on the ceramics of the Northern Carpathian group (Maczyńska 2005, 157; Madyda-Legutko 1996, 97, 98; Pieta 1991, 383; 2009, 119; cf. Madyda-Legutko/Tunia 2008, 246) was once again confirmed.

\section{ROMAN MORTARIUM \\ FROM THE 'PRINCELY' GRAVE IN POPRAD-MATEJOVCE}

\section{Typological affiliation and chronology}

In addition to the above-mentioned seven ceramic vessels from the barbarian environment, the grave in Poprad-Matejovce contained one provincial Roman glazed mortarium, which is the subject of the present study (Fig. 1). It is a specimen made on a potter's wheel, resembling an inverted, truncated cone, with a crescent-shaped rim and a gutter-shaped

\footnotetext{
1 The only exception is perhaps the sepulchral site at Rajbrot, małopolskie voj. (PL; cf. Biborski/Zagórska-Telega 2008).
} 

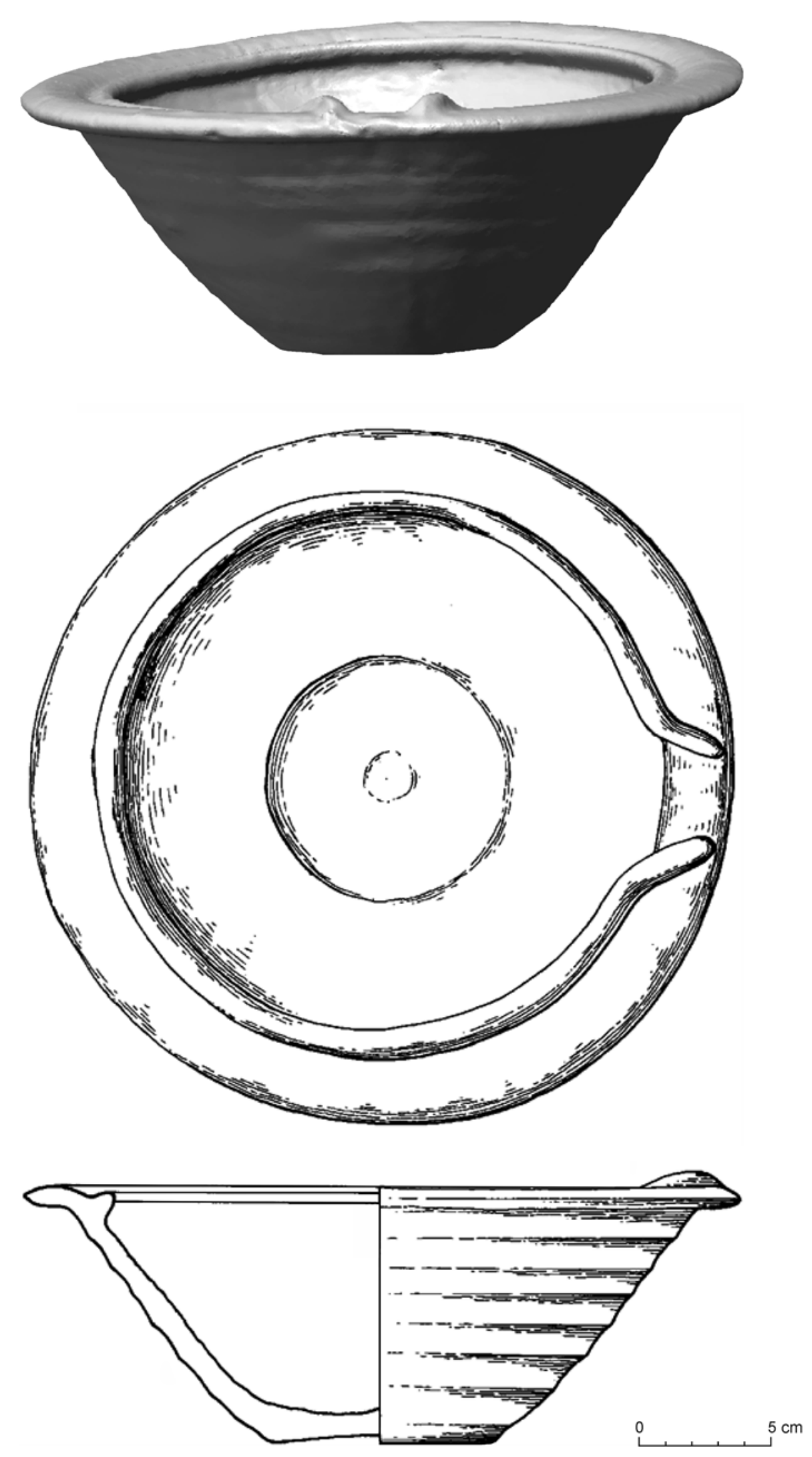

Fig. 1. Poprad-Matejovce. The Roman mortarium (drawn N. Vaššová). 
spout (dimensions: total height $10 \mathrm{~cm}$; spout diam. $26 \mathrm{~cm}$; bottom diam. $8.3 \mathrm{~cm}$ ). The outer surface, pale greyish in colour with small dark glaze patches, is smooth but slightly rough, while the inner surface is intentionally roughened, also with traces of a green-yellowish glaze, the remains of which were also preserved on the surface of the crescent-shaped rim (Rodzińska-Nowak, forecoming).

Similar specimens have been included in the $13^{\text {th }}$ group of Roman form mortaria according to the classification system of R. P. Symonds (2012). The author classified conical vessels occurring in the $2^{\text {nd }}$ and $3^{\text {rd }}$ c. mainly in Moesia and Dacia, as well as in Pannonia, into the above-mentioned group. It was from these forms in Moesia Superior and Pannonia that mortaria characteristic of the later period, covered with lead glaze, were to develop (Symonds 2012, 184-188, fig. 11; 12). The presence of traces of glaze inside the vessel, as in the case of the mortarium from Poprad-Matejovce, is considered to be a feature indicating a late antique metric (Bru Calderón 2011, 25). This specimen finds analogues among mortaria known, among others, from the Zlechov settlement in Moravia (Zeman 2006, 462, fig. 7: 17; 2008, 68-71, fig. 17: 1-3) and from the St. Pölten-Rathausplatz site in Lower Austria (Bru Calderón 2011, pl. II: 4, 5). It is reasonable to believe that the vessel in question comes from Pannonia, where glazed mortaria were produced on a large scale from the mid- $4^{\text {th }} \mathrm{c}$. onwards. It is probably from there that they reached the southern Barbaricum zone, where they enjoyed considerable popularity (Groh/Sedlmayer 2002, 303; Grünewald 1979, 68; 1992; Krekovič 1973; RodzińskaNowak, forecoming; Zeman 2008, 70, 71).

Glazed mortaria are found in large numbers in the provinces of the Roman state at sites dated to the end of the $3^{\text {rd }} c$. and the $4^{\text {th }} c$., and their presence is considered to be an indicator of the degree of acculturation of the local population, manifested among other things in the adoption of typically Roman models in the culinary arts. These vessels were in fact mainly used for grinding foodstuffs, e.g. herbs, spices, seeds, fruits, salt, etc., as well as for grinding sauces, preparing flour dishes or dairy products, such as moretum - a type of herbal cheese eaten with bread mentioned in Roman written sources (Apicius, De re coquinaria, I, 35; Cramp/ Evershed/Eckardt 2011, 1341; cf. Bru Calderón 2011, 25). Finds of vessels of this type are known, as mentioned, also from the southern zone of central European Barbaricum, where they occur both on settlements and in sepulchral contexts. Mortaria were discovered, among others, on settlements in Branč, Nitra distr. (SK; Kolník/Varsik/Vladár 2007, pl. 24: 12; 68: 6; 145: 3, 4), Štúrovo, Nové Zámky distr. (SK; Beljak/Kolník 2008, 78), Drslavice and Zlechov,
Uherské Hradiště distr. (CZ), Pasohlávky, Brnovenkov distr. (CZ; Tejral 2002, 355; Zeman 2006; 2008, 68-71), Maiersch, Horn distr. (A; Pollak 1980, 66, pl. 44: 4; 59: 8) and Ringelsdorf, Gänserndorf distr. (A; Allerbauer/Jedlicka 2000, 660, fig. 788). The chronological position of glazed mortars from the above-mentioned settlements has been usually fixed to the second half of the $4^{\text {th }} \mathrm{c}$. and the first half of the $5^{\text {th }}$ c. (Krekovic 1973, 102; Tejral 1999, 229; Varsik 1998, 50, 85; 2004, 262; Zeman 2008, 68-71). Finds of such vessels are also attested in cemeteries, including Pohořelice, Brno-venkov distr. (CZ; Čižmář 1997, 26, fig. 7: 13) or Abrahám, Galanta distr. (SK; Kolník 1973, 386, fig. 29: 4a-c).

The assemblage of ceramics of barbarian origin discovered in the 'princely' tomb at Poprad-Matejovce is chronologically consistent and can be dated to phases C3-D, and the chronological position of the imported mortarium fully confirms the above dating of this assemblage.

\section{Alleged function during a funerary ceremony}

All the above-mentioned ceramic vessels forming part of the equipment of the grave at PopradMatejovce, including the mortarium in question, were discovered, as already mentioned, between the walls of the inner and outer chamber of the grave in the vicinity of a Hemmoor bucket, a basket made of bast and a cluster of animal bones accompanied by a knife (Lau 2013, 17, 19; Lau/Pieta 2010, 350, fig. 8; 2017, 258, fig. 3; Pieta 2009, 116, fig. 14). A detailed analysis of the traces associated with the reopening and robbery of a tomb in antiquity by $\mathrm{N}$. Lau and $\mathrm{K}$. Pieta proved that the pottery, together with the objects in its vicinity, was probably in situ at the time of discovery in 2006, i.e. it did not bear any signs of displacement, although five vessels, including the mortarium in question, had been broken, probably during the robbery of the tomb (Lau/Pieta 2017, 258; Pieta 2009, 116). It is therefore possible to speculate that the vessels were located in a zone where gifts of food intended for the deceased were deposited, which seems to be supported in particular by the presence of the aforementioned animal bones, among which were the remains of a piglet and possibly a deer. It should also be noted that the presence of hazelnuts was recorded within the inner chamber, which may have both been a source of food and may have had some symbolic significance in funerary rituals (Lau 2013, 19; Pieta 2009, 116; cf. Andrzejowski 2011, 187, fig. 7; Dąbrowska 2008, 145; Nieweegłowski 1993; Schuster 2014, 36).

We may risk a statement that a hand-made bowl of considerable size together with six small vessels 
(bowls), three of which are also hand-made, and three more made by means of a potter's wheel, constitute a service for a communal consumption of an alcoholic beverage. A large hemispherical bowl probably served as a container for storing this drink (Rodzińska-Nowak, forecoming). Based on the results of the analysis of the contents of some vessels known from other graves of representatives of barbarian elites, it can be assumed that the beverage could have been, for example, beer sweetened with honey or mead, although the presence of wine or fruit wine cannot also be categorically excluded (cf. Crane 1999, 515; Jahns 2001; Hellmund 2010, 252, 253, 261; Körber-Grohne 1985, 121, 122; Rodzińska-Nowak 2018, further literature therein). Looking at the set of six different, not always carefully crafted, bowls accompanying the large bowl, however, it is hard to resist the impression that they fit neither the grandiose form of the grave at Poprad-Matejovce nor, still less, the colloquial notions of 'princely' tableware. This observation leads us in this case to consider the validity of $\mathrm{H}$. Steuer's conception that sets of dishes and fragments of animal carcasses found in the burials of elites were not originally intended for the deceased, but are a trace of a feast accompanying a funeral ceremony (Totenmahl). This feast was intended, among other things, to reflect the existing hierarchy in the community, i.e. the division between rulers and ruled, and any remains of it were ritually deposited in the grave (Steuer 2006, 14, 20; cf. Schuster 2014, 29). If we assume that the aforementioned concept accurately explains the situation observed in the case of the grave from Poprad-Matejovce, the question arises what function the imported provincial Roman mortarium could have had in the funerary rites?

The manifestations of strong Roman influence evident both in the form of the grave from PopradMatejovce and in certain elements of its furnishings have already been repeatedly pointed out in the literature. In particular, the construction of the inner chamber, topped with a gabled roof modelled on some Roman tombs and sarcophagi (Lau/Pieta 2010, 350; 2017, fig. 6, 8, 10), was pointed out, as well as the presence of a wooden bed, finding analogies among luxurious Roman furniture, depictions of which are known from iconographic sources from the turn of the $4^{\text {th }}$ and $5^{\text {th }}$ c. (Lau 2017). Following this line of thought, is it possible to think that the mortarium placed in the burial proves the reception in the deceased's immediate environment of Roman customs related to the preparation of meals?

According to some authors, the relatively numerous presences of imported provincial Roman mortars in the settlements of the barbarian population settled in the Danube zone can be regarded as a sign of their romanisation and seems to support their adoption, to some extent, of Roman culinary customs (cf. Kolník 1994, 250). However, it should be stated that, based on the currently available sources, both archaeological and biological, it is very difficult to assess what might have been the scale of the influence of Roman patterns in terms of dietary patterns or ways of preparing meals on the population of the aforementioned zone of the Barbaricum (cf. Hajnalová/Varsik 2010). According to some scholars, however, the presence of mortaria can be interpreted not as a direct reflection of the 'romanisation' of dietary modes, but rather as a manifestation of a more complex process of cultural adaptation of this type of vessel, both within and outside the kitchen (cf. Cramp/Evershed/ Eckardt 2011, 1350).

On the other hand, it has to be said that Roman patterns of behaviour were sometimes followed by representatives of the upper strata of barbarian communities. This can be confirmed by a case recorded in Thuringia, where in Haarhausen, Ilm distr. (D) a pottery workshop was discovered, dated to the second half of the $3^{\text {rd }}$ c., producing, probably for the needs of the local elite, pottery according to Roman models, including mortaria (Dušek 1984; 1992). It is worth noting that at the same time in the mentioned area there is evidence of a different structure of herds of cattle, and presumably also of sheep, which shows characteristics of the Mediterranean circle (Benecke 1994, 151; Rodzińska-Nowak 2012, 116). This seems to further support the thesis that the local elite adopted Roman patterns in the field of economy and perhaps even diet. It is worth emphasising that so far, no mortaria have been found in the Odra or Vistula basins. An isolated and unexpected discovery, however, is a fragment of such a vessel, encountered at the Vorbasse settlement in central Jutland (DK) (Lund Hansen 2014).

Coming back to the discussed mortarium find from the grave in Poprad-Matejovce, it should be stated that among the wooden objects preserved inside the mentioned grave, no remains of a club, with which foodstuffs were usually crushed or ground in a mortar, were found. We also do not have the results of specialist analyses, which could provide a basis for inferring its contents. In view of the above, we can only assume that the mortarium placed in the 'princely' tomb, near the set of vessels intended for the consumption of alcoholic beverages and fragments of animal carcasses, contained a dish (e.g. cheese, meat sauce, flour dish?) which was part of the feast accompanying the funeral ceremony. Given the use of a mortar, it seems likely that the recipe for this dish may have been more or less borrowed from Roman culinary tradition. 
Considering the above-mentioned manifestations of the Roman culture influence visible both in the construction of the tomb from Poprad-Matejovce and in certain elements of its furnishing, it is worth considering yet another possible interpretation of the function of the discussed mortarium during the funeral ceremony. It should be remembered that the use of these vessels in the Roman world sometimes went far beyond the kitchen function. Among other things, they were useful for making medicines and cosmetics, for grinding dyes, but they were also used as containers for burning incense, and as lamps (Droberjar 2005, 67; Kolník 1973, 386; Krekovič 1973, 99, 100; Symonds 2012, 169-172, 187, 188).

Both the results of the analysis of ancient written sources and the results of the study of archaeological artefacts suggest that light played an important role in Roman funerary customs (cf. Madyda-Legutko 2017, 412, 417; Menzel 1953; von Schnurbein 1977, 54-72; Winniczuk 1983, 465). Light sources in the form of olive lamps were therefore a common element of tomb furnishings in the Roman world, and they also occur in large numbers in archaeological contexts indicating that they performed various ritual functions, including votive gifts and magical objects (Diosono 2020; Diosono/Cinaglia 2016). The presence of imported Roman olive lamps is also attested in Barbaricum, but they are among the relatively few finds. Clay specimens predominate among them, although specimens described in the literature as bronze are also known. The artefacts of the discussed category are found on settlements and sometimes also on sepulchral sites, which allows us to believe that they were given a certain symbolic meaning also in the native, i.e. barbarian funerary ritual (cf. Madyda-Legutko 2017, 417). Finds of these imports are concentrated in the near-limes zone, in the middle Danube basin (south-western Slovakia, Moravia, Lower Austria), on the Rhine, between the Rhine and the Weser, and on the Lippe River (Hrnčiarik 2013a, 166, map 77; Jančo 2001, map 2; Krekovič 1996, fig. 1; Madyda-Legutko 2017, 411). In other areas they occur in dispersion, although there are areas so far completely devoid of finds of these monuments. This observation applies, for example, to Scandinavia (cf. Lund Hansen 1987).

The presence of imported olive lamps is also attested in the Slovak part of the Carpathians. Two lamps are known from the settlement area of the Púchov culture, which should most probably be associated with the eponymous settlement of this unit in Púchov (SK) on the Váh river and dated to the second half of the $2^{\text {nd }}$ c. AD (Hrnčiarik 2013a,
167; 2013b, 142, inv. no. 2102, 2103; pl. XC: 2102, 2103; Krekovič 1983, 512, 513, 515, pl. I: 8, 9; 1996, 142; Madyda-Legutko 2017, 415). In addition, several fragments of North African lamps come from a settlement of the Northern Carpathian group population at Kežmarok-Vrbov, Kežmarok distr., dated to the end of the Late Roman period and the early phase of the Migration Period (Giertlová-KučeroválSoják 2005, 114, 123, fig. 3: 2; Hrnčiarik 2013a, 167; 2013b, 163, 164, inv. no. 2369-2372; pl. XC: 2369-2372; Pieta 1991, 378, fig. 2: 27, 28), of which three fragments, from a workshop in central Tunisia, are dated to 330-370 (Hrnčiarik 2013a, 167; Madyda-Legutko 2017).

In the context of the present discussion, the find of a bronze two-burner lamp of the Mahdia type discovered in a 'royal' grave in Mušov, Mikulov distr. (CZ), in the southern part of Moravia, dated to the period immediately before the Markomanic Wars, deserves particular attention. Inside the lamp, linen fibres were found, probably originally constituting its wick, which allows us to conclude that it was used for its intended purpose (Künzl/Künzl 2002, 581; Opravil 2002, 490). The lamp represents a type dated to the reign of Augustus, so its chronological position is much older than the date it was placed in the grave (Künzl 2002, 471, 472; Peška/Tejral 2002, 502). The inventory of this burial included other objects of an 'antiquarian' nature, which suggests that they were collected over a longer period of time by representatives of the local elite (Peška/Tejral 2002, $509,510)$. The placement of the lamp in the grave may support the view that the surroundings of the deceased adopted certain beliefs and eschatological ideas, borrowed from the provincial Roman environment. The presence of yet other imports in the inventory of this burial also seems to testify to the adaptation of Roman patterns of behaviour (Madyda-Legutko 2017, 417, 418; Peška/Tejral 2002, 502).

Relatively little is known about the light sources of native origin used by the people of Barbaricum (cf. Hegewisch 2005, 93; 2006, 269; 2009; 2010; Wunderlich 2002). There are indications that rooms were lit using wax or tallow candles, ${ }^{2}$ which were known in the ancient world (Hegewisch 2010, 194-197; Madyda-Legutko 2017, 413; Wunderlich 2000, 83-86). Some researchers suppose that the function of lamps could have been performed by some forms of ceramic vessels (cf. Hegewisch 2009; 2010). There is a view in the literature that the so-called Dacian bowls, found not only in areas inhabited by the Dacians, but also in areas where contacts with this cultural milieu are attested, may have been used as lamps. These bowls, characterised by a specific form, are found throughout

\footnotetext{
2 In the 'princely' grave in Poprad-Matejovce, a wooden disc was found, which was interpreted as a candlestick in the catalogue of artefacts forming part of the monograph on this grave that is being prepared for publication.
} 
the Roman period (Egri/Rustoiu 2008, 84; Istvánovits/ Pintye 2011, 103; Madyda-Legutko 2017, 414). It is worth mentioning that very similar forms of ceramic vessels found in Gaul are clearly interpreted as lamps (cf. Delor-Ahü/Kasprzyk 2006, 59, fig. 5).

In view of the above, it is possible to speculate that the provincial Roman mortarium discovered in the 'princely' grave at Poprad-Matejovce could have been used as a lamp, as was sometimes the case in the Roman world (cf. Droberjar 2005, 67; Krekovič 1973, 99, 100; Symonds 2012, 169-172, 187, 188). For example, a vessel is known from Apulum (Moesia Superior), like the specimen from PopradMatejovce representing the $13^{\text {th }}$ mortar group in the classification according to R. P. Symonds (2012), with clear traces of soot inside, probably used as a light source or possibly as a container for burning incense (Bjelajac 1992-1993, 139, 140; Symonds 2012, 187, 188, fig. 12: 135). In order for the mortarium to serve as a lamp it seems likely that it will be filled for this purpose with beef tallow, fish fat or vegetable oil, e.g. linseed oil. The wick could have been made of plant fibres, e.g. flax, analogous to the lamp from the burial at Mušov (Hegewisch 2010, 194-197; Hrnčiarik 2013a, 168, 169; Opravil 2002, 490). However, we should caveat that so far, we do not have the results of analyses that would certify the presence of residues of burnt fat inside vessels known from the Barbaricum site (cf. Madyda-Legutko 2017, 413). This remark also applies to the mortarium in question, broken during grave robbing.

\section{CONCLUSION}

In conclusion, it should be stated that the magnificent form of the 'princely' grave at PopradMatejovce, as well as some of its preserved furnishings, such as the wooden bed, undoubtedly prove the strong influence of Roman culture on the elite population living in the southern zone of Barbaricum at the end of antiquity (cf. Lau 2017; Lau/Pieta 2010, 350; 2017, fig. 6, 8, 10). The presence of a glazed mortarium is one of the manifestations of the aforementioned interactions. This vessel can most probably be interpreted as part of the tableware used during the feast accompanying the funerary ceremony (Totenmahl). It presumably contained a dish, the recipe of which may have been related to Roman culinary customs to some extent. However, bearing in mind the numerous and varied uses of Roman mortars, some of which were completely unrelated to the culinary arts, we cannot categorically exclude the possibility that the vessel may have served as a source of light during funerary ceremonies. Indeed, light played an important role in Roman funerary customs, and the presence of imported lamps in some graves of the Barbarians is interpreted as one of the evidences of the adoption by this population of certain eschatological imagery originating from the provincial Roman culture (cf. Józefów 2009; Madyda-Legutko 2017, 413; Rodzińska-Nowak 2006; Rodzińska-Nowakl Zagórska-Telega 2007, 269, 270; Witteyer 1993).

\section{BIBLIOGRAPHY}

Allerbauer/Jedlicka 2000 - S. Allerbauer/F. Jedlicka: KG Ringelsdorf, MG Ringelsdorf-Niederabsdorf, VB Gänserndorf. Fundberichte aus Österreich 39, 2000, 660, 661.

Andrzejowski 2011 - J. Andrzejowski: Out of the social structure? A Late Roman Period female grave from Jartypory, Eastern Poland. In: D. Quast (Hrsg.): Weibliche Eliten in der Frühgeschichte. Female elites in protohistoric Europe. Internationale Tagung vom 13. bis zum 14. Juni 2008 im RGZM im Rahmen des Forschungsschwerpunktes "Eliten«. Römisch-Germanischen Zentralmuseum. Tagungen 10. Mainz 2011, 185-199.

Apicius - Marcus Gavius Apicius: De re coquinaria = Apicjusz. O sztuce kulinarnej. Ksiag dziesięć. Tekst, przekład i komentarz I. Mikołajczyk, S. Wyszomirski. Toruń 2012.

Beljak/Kolník 2008-J. Beljak/T. Kolník: Germanic settlement from the Late Roman and Early Migration periods in Štúrovo. In: Niezabitowska-Wiśniewska et al. eds. 2008, 65-88.

Benecke 1994 - N. Benecke: Archäozoologische Studien zur Entwicklung der Haustierhaltung in Mitteleuropa und Südskandinavien von den Anfängen bis zum ausgehenden Mittelalter. Schriften zur Ur- und Frühgeschichte 46. Berlin 1994.
Biborski/Zagórska-Telega 2008 -M. Biborski/J. Zagórska-Telega: Rajbrot, site 4, commune: Lipnica Murowana-Migration Period cemetery. In: Niezabitowska-Wiśniewska et al. eds. 2008, 89-96.

Bjelajac 1992-1993 - L. Bjelajac: Mortaria in the Moesia Danube valley. Starinar NS 43-44, 1992-1993, 139-148.

Bru Calderón 2011 - M. Bru Calderón: Spätantike glasierte Keramik aus der Grabung St. Pölten-Rathausplatz. Diplomarbeit. Institut für Klassische Archäologie. Universität Wien. Wien 2011.

DOI: https://doi.org/10.25365/thesis.17851

Čižmář 1997 - M. Čižmář: Das Gräberfeld der Völkerwanderungszeit in Pohořelice (Bez. Břeclav), In: J. Tejral/ H. Friesinger/M. Kazanski (Hrsg.): Neue Beiträge zur Erforschung der Spätantike im mittleren Donauraum. Materialen der Internationalen Fachkonferenz. Kravsko 17.-20. Mai 1995. Spisy Archeologického ústavu AV ČR Brno 8. Brno 1997, 23-30.

Cramp/Evershed/Eckardt 2011 - L. J. E. Cramp/R. P. Evershed/H. Eckardt: What was a mortarium used for? Organic residues and cultural change in Iron Age and Roman Britain. Antiquity 85, 2011, 1339-1352. DOI: https://doi.org/10.1017/S0003598X00062098 
Crane 1999 - E. Crane: The World History of Beekeeping and Honey Hunting. Routledge - New York 1999.

Dabrowska 2008 - T. Dąbrowska 2008: Młodszy okres przedrzymski na Mazowszu i zachodnim Podlasiu. Zarys kulturowo-chronologiczny. Materiały Starożytne i Wczesnośredniowieczne 7. Warszawa 2008.

Delor-Ahü/Kasprzyk 2006 - A. Delor-Ahü/M. Kasprzyk: Rouilly-Saint-Loup, "établissement de défense" (Aube). Découverte d'un lot céramique spécifique. Bulletin de la Société Archéologique Champenoise 99/4, 2006, $54-59$.

Diosono 2020 - F. Diosono: Lamps as ritual and 'magical' objects in archaeological contexts. In: A. Mastrocinque/ J. E. Sanzo/M. Scapini (eds.): Ancient magic. Then and now. Potsdamer Altertumswissenschaftliche Beiträge 74. Stuttgart 2020, 139-157.

Diosono/Cinaglia 2016 - F. Diosono/T. Cinaglia: Light on the water: ritual deposit of lamps in Lake Nemi. Journal of Roman Archeology 29, 2016, 451-468.

Droberjar 2005 - E. Droberjar 2005: Věk barbario. České země a stěhování národů z pohledu archeologie. Praha - Litomyšl 2005.

Dušek 1984 - S. Dušek: Die Produktion römischer Drehscheibenkeramik in Thüringen - Technologie, ökonomische und gesellschaftliche Konsequenzen. In: R. Feustel (Hrsg.): Römerzeitliche Drehscheibenware im Barbaricum. Weimarer Monographien zur Ur- und Frühgeschichte 11. Weimar 1984, 5-18.

Dušek 1992 -S. Dušek: Römische Handwerker im germanischen Thüringen. Ergebnisse der Ausgrabungen in Haarhausen, Kreis Arnstadt. Fundbericht. Weimarer Monographien zur Ur- und Frügeschichte 27. Teil A, B. Stuttgart 1992.

Egri/Rustoiu 2008 - M. Egri/A. Rustoiu: Imported lamps from pre-Roman Dacia. In: C. A. Roman/N. Gudea (eds.): Trade and local production of lamps from Prehistory until the Middle Age. Lychnological Acts 2. Cluj-Napoca 2008, 79-86, pl. 30-33.

Giertlová-Kučerová/Soják 2005 - M. Giertlová-Kučerová/ M. Soják: Novšie nálezy severokarpatskej skupíny v povodí rieky Poprad. Študijné zvesti AÚ SAV 38, 2005, 113-136.

Groh/Sedlmayer 2002 - S. Groh/H. Sedlmayer: Forschungen im Kastell Mautern-Favianis. Die Grabungen der Jahre 1996 und 1997. Der römische Limes in Österreich 42. Wien 2002.

Grünewald 1979 - M. Grünewald: Die Gefässkeramik des Legionslagers von Carnuntum (Grabungen 1968-1974). Der römische Limes in Österreich 29. Wien 1979.

Hajnalová/Varsik 2010 - M. Hajnalová/V. Varsik: Kvádske rol’níctvo na Slovensku z pohl'adu archeológie a archeobotaniky. In: J. Beljak/G. Březinová/V. Varsik (eds.): Archeológia barbarov 2009. Hospodárstvo Germánov, sídliskové a ekonomické štruktúry od neskorej doby laténskej po včasný stredovek. Zborník referátov z 5. protohistorickej konferencie. Nitra 21.-25. septembra 2009. Archaeologica Slovaca Monographiae. Communicationes 10. Nitra 2010, 181-224.

Hegewisch 2005 - M. Hegewisch: Germanische Nachahmungen römischer Metall-, Glas- und Keramikgefäße - eine kurze Übersicht. Památky archeologické 96, 2005, 79-104.

Hegewisch 2006 - M. Hegewisch: Germanische Adaptionen römischer Importgefäße. Bericht der Römisch-Germanischen Kommission 86, 2006, 197-348.
Hegewisch 2009 - M. Hegewisch: Lampen im Barbaricum. Ein kurzer Beitrag zur Beleuchtung in germanischen Siedlungen. In: K. Myzgin (Hrsg.): Ostrogothica. Archäologie des Zentral- und Osteuropas in der Späten Römischen Kaiserzeit und der Völkerwanderungszeit. Sammelband der wissenschaftlichen Schriften zum 10. Jahrestag der Germanisch-Slawischen archäologischen Expedition der Charkover-Nationalen-V.-N. Karazin-Universität. Charkov 2009, 19-33.

Hegewisch 2010 - M. Hegewisch: Lampen im Barbaricum. Ein Beitrag zur Beleuchtung in germanischen Siedlungen. In: T. Armbruester/M. Hegewisch (Hrsg.): Beiträge zur Vor- und Frühgeschichte der Iberischen Halbinsel und Mitteleuropas. Studien in honorem Philine Kalb. Studien zur Archäologie Europas 11. Bonn 2010, 193-228.

Hellmund 2010 - M. Hellmund: Honigreste in einem Eibenholzeimer aus dem Fürstengrab von Gommern. In: M. Becker: Das Fürstengrab von Gommern. Veröffentlichungen des Landesamtes für Denkmalpflege und Archäologie Sachsen-Anhalt-Landesmuseum für Vorgeschichte 63. Band 1. Halle/Saale 2010, 247-261.

Hrnčiarik 2013a - E. Hrnčiarik: Römisches Kulturgut in der Slowakei. Herstellung, Funktion und Export römischer Manufakturerzeugnisse aus den Provinzen in der Slowakei. Teil 1. Universitätsforschungen zur prähistorischen Archäologie 222. Bonn 2013.

Hrnčiarik 2013b - E. Hrnčiarik: Römisches Kulturgut in der Slowakei. Herstellung, Funktion und Export römischer Manufakturerzeugnisse aus den Provinzen in der Slowakei. Teil 2. Universitätsforschungen zur prähistorischen Archäologie 222. Bonn 2013.

Istvánovits/Pintye 2011 - E. Istvánovits/G. Pintye: Az alföldi Barbaricum mécsesei. A nyíreoyházi Jósa András Múzeum Ėvkönyve 53, 2011, 83-111.

Jahns 2001 - S. Jahns: Zum Pollenspektrum im Fürstengrab 9/1995. In: F. Lüth/H. U. Voß: Neue Römergräber aus Hagenow - ein Vorbericht. Bodendenkmalpflege in Mecklenburg-Vorpommern. Jahrbuch 48, 2001, 199-202.

Jančo 2001 - M. Jančo: Nálezy lámp z doby rímskej v Čechách. Památky archeologické 92, 2001, 165-183.

Józefów 2009 - B. Józefów: Problematyka identyfikacji i badań obiektów kremacji w okresie rzymskim - busta, ustryny i jednorazowo wykorzystane miejsca kremacji (Badania miejsc kremacji). In: W. Dzieduszycki/J. Wrzesiński (red.): Metody. Źródła. Dokumentacja. Funeralia Lednickie 11. Poznań 2009, 225-239.

Kolník 1973 - T. Kolník: Pohrebisko z doby stahovania národov v Abraháme. Slovenská archeológia 21, 1973, 359-399.

Kolník 1994 - T. Kolník: Zur Verbreitung und Beliebheit der Reibschalen und deren Nachahmungen bei den swebischen Germanen (Quaden). Alba Regia 25, 1994, 249-252.

Kolník/Varsik/Vladár 2007 - T. Kolník/V. Varsik/J. Vladár: Branč. Germánska osada z 2. až 4. storočia. Archaeologie Slovaca Monographie. Catalogi 10. Nitra 2007.

Körber-Grohne 1985 - U. Körber-Grohne: Pflanzliche und tierische Reste aus dem Fürstengrab von Hochdorf. Die Biologie als Hilfswissenschaft der Archäologie. In: D. Planck/J. Biel/G. Süsskind/A. Wais (Hrsg.): Der Keltenfürst von Hochdorf, Methoden und Ergebnisse der Landesarchäologie in Baden-Württemberg. Stuttgart 1985, 117-123.

Krekovič 1973 - E. Krekovič: Zur Frage der Reibschüsseln. Musaica 13, 1973, 99-107. 
Krekovič 1983 - E. Krekovič: Römische Lampenfunde im slowakischen Barbaricum. Archeologické rozhledy 35, 1983, 510-516, 595.

Krekovič 1996 - E. Krekovič: Römische Lampen im freien Germanien und in Osteuropa. In: Acta Rei Cretariae Romanae Fautorum 33. Congressus undevicesimus Rei Cretariae Romanae Fautorum in Dacia habitus 1994. Timişoara 1996, 141-144.

Künzl 2002 - S. Künzl: Zwei Antiquitaten aus der Zeit des Kaisers Augustus: Lampe und Klapptisch. In: Peškal Tejral Hrsg. 2002/2, 471-474.

Künzl/Künzl 2002 -S. Künzl/E. Künzl: Römische Metallobjekte und anderes. In: Peška/Tejral Hrsg. 2002/3, 581-596.

Lau 2013 - N. Lau: Das Grab von Poprad-Matejovce in der Slovakei - Ein Blockhaus mit Inneneinrichtung aus der frühen Völkerwanderungszeit. Archäologische Nachrichten aus Schleswig-Holstein 19, 2013, 16-19.

Lau 2017 - N. Lau: Überlegungen zur gedrechselten Totenliege aus dem frühvölkerwanderungszeitlichen Grab von Poprad-Matejovce. In: B. V. Eriksen/A. AbeggWigg/R. Bleile/U. Ickerodt (Hrsg. - eds.): Interaktion ohne Grenzen. Beispiele archäologischer Forschungen am Beginn des 21. Jahrhunderts. Band I - Interaction without borders. Exemplary archaeological research at the beginning of the $21^{\text {st }}$ century. Volume I. Schleswig 2017, 457-466.

Lau/Pieta 2010 - N. Lau/K. Pieta: Das Grab von PopradMatejovce in der Slowakei-Konstruktion, Ausstattung und Wiederöffnung eines frühvölkerwanderungszeitlichen Kammergrabes. In: A. Abegg-Wigg/N. Lau (Hrsg.): Kammergräber im Barbaricum. Zu Einflüssen und Übergangsphänomenen von der vorrömischen Eisenzeit bis in die Völkerwanderungszeit. Schriften des Archäologischen Landesmuseums Ergänzungsreihe 9. Neumünster - Hamburg 2010, 343-364.

Lau/Pieta 2017 - N. Lau/K. Pieta: Die Antike Öffnung des Kammergrabes von Poprad-Matejovce. In: Na hranicích Impéria. Extra fines Imperii. Jaroslavu Tejralovi k 80. narozeninám. Brno 2017, 255-265.

Lund Hansen 1987 - U. Lund Hansen: Römischer Import im Norden. Warenaustausch zwischen dem römischen Reich und dem freien Germanien während der Kaiserzeit unter besonderer Berücksichtigung Nordeuropas. Nordiske Fortidsminder. Serie B. Band 10. København 1987.

Lund Hansen 2014 - U. Lund Hansen: Ein Reibschalenfragment aus Vorbasse (Region Syddanmark/Dk) - erster Fund von Reibschalen in Skandinavien. In: RömischGermanisches Zentralmuseum (Hrsg.): Honesta Missione. Festschrift für Barbara Pferdehirt. Monographien des Römisch-Germanischen Zentralmuseums. Band 100. Mainz 2014, 445-454.

Mączyńska 2005 - M. Mączyńska: Zanik kultury przeworskiej. In: P. Kaczanowski/M. Parczewski (red.): Archeologia o poczatkach Stowian. Materiały z konferencji, Kraków, 19-21 listopada 2001. Kraków 2005, 157-163.

Madyda-Legutko 1996 - R. Madyda-Legutko: Zróżnicowanie kulturowe polskiej strefy beskidzkiej w okresie lateńskim i rzymskim. Uniwersytet Jagielloński. Rozprawy habilitacyjne nr 304/1. Kraków 1996.

Madyda-Legutko 2017 - R. Madyda-Legutko: Rola światła w życiu codziennym i w obrzędowości pogrzebowej ludności środkowoeuropejskiego Barbaricum. In: J. Miziołek/J. Gancarski/A. Guz-Iwaniec (red.): Światło w dziejach człowieka, sztuce, religii, nauce itechnice 1. Krosno 2017, 411-433.
Madyda-Legutko/Tunia 2008 - R. Madyda-Legutko/ K. Tunia: Late Roman and Early Migration Period in Polish Beskid Mts., Carpathians. Settlement aspect. In: Niezabitowska-Wiśniewska et al. eds. 2008, 227-248.

Menzel 1953 - H. Menzel: Lampen im römischen Totenkult. In: H. Klumbach (Hrsg.): Festschrift des RömischGermanischen Zentralmuseums in Mainz zur Feier seines hundertjährigen Bestehens 1952. Band 3. Mainz 1953, 131-138.

Niewęgłowski 1993 - A. Niewęgłowski: Leszczyna i orzechy laskowe jako materialne korelaty religii w Polsce przedchrześcijańskiej. In: M. Kwapiński/H. Paner (red.): Wierzenia przedchrześcijańskie na ziemiach polskich. Gdańsk 1993, 47-55.

Niezabitowska-Wiśniewska et al. eds. 2008 -B. NiezabitowskaWiśniewska/M. Juściński/P. Łuczkiewicz/S. Sadowski (eds.): The Turbulent Epoch. New materials from the Late Roman Period and the Migration Period. Monumenta Studia Gothica 5. Lublin 2008.

Opravil 2002 - E. Opravil: Bestimmung der Pflanzenreste. In: Peška/Tejral Hrsg. 2002/3, 488-490.

Peška/Tejral 2002 - J. Peška/J. Tejral: Gesamtinterpretation des Königsgrabes von Mušov. In: Peška/Tejral Hrsg. 2002/2, 501-513.

Peška/Tejral Hrsg. 2002 - J. Peška/J. Tejral (Hrsg.): Das germanische Königsgrab von Mušov in Mähren. Teil 1-3. RömischGermanisches Zentralmuseum. Monographien 55. Mainz 2002

Pieta 1991 - K. Pieta: The North Carpathians at the beginning of the Migration Period. Antiquity 65, 1991, 376-387. DOI: https://doi.org/10.1017/S0003598X00079886

Pieta 2009 - K. Pieta: Das germanische Fürstengrab aus Poprad-Matejovce. In: U. von Freeden/H. Friesinger/ E. Wamers (Hrsg.): Glaube, Kult und Herrschaft. Phänomene des Religiösen im 1. Jahrtausend n. Chr. in Mittel-und Nordeuropa. Akten des 59. Internationalen Sachsensymposions und der Grundprobleme der frühgeschichtlichen Entwicklung im Mitteldonauraum. Kolloquien zur Vorund Frühgeschichte 12. Bonn 2009, 107-122.

Pollak 1980 - M. Pollak: Die germanischen Bodenfunde des 1.-4. Jahrhunderts nach Chr. im nördlichen Niederösterreich. Denkschriften Österreichische Akademie der Wissenschaften 147. Wien 1980.

Rodzińska-Nowak 2006 - J. Rodzińska-Nowak: Zoomorficzna plastyka figuralna z cmentarzysk kultury przeworskiej. In: L. Kostuch/K. Ryszewska (red.): Zwierze jako sacrum w pradziejach i starożytności I. Kielce 2006, 11-25.

Rodzińska-Nowak 2012 - J. Rodzińska-Nowak: Gospodarka żywnościowa ludności kultury przeworskiej. Opera Archeologiae Iagellonicae 2. Kraków 2012.

Rodzińska-Nowak 2018 - J. Rodzińska-Nowak: Napoje alkoholowe mieszkańców Barbaricum. In: B. NiezabitowskaWiśniewska/P. Łuczkiewicz/S. Sadowski/M. StasiakCyran/M. Erdrich (red.): Studia Barbarica. Profesorowi Andrzejowi Kokowskiemu w 65. rocznice urodzin. Tom II. Lublin 2018, 580-588.

Rodzińska-Nowak, forecoming - J. Rodzińska-Nowak: Die Keramik aus dem „Fürstengrab” in Poprad-Matejovce. In: M. Ruttkay/C. von Carnap-Bornheim (Hrsg.): Das Kammergrab von Poprad-Matejovce 1. Nitra - Schleswig, forecoming.

Rodzińska-Nowak/Zagórska-Telega 2007 - J. RodzińskaNowak/J. Zagórska-Telega: Uwagi na temat obrządku 
pogrzebowego na cmentarzysku kultury przeworskiej w Opatowie, stan. 1, woj. śląskie. Acta Universitatis Lodziensis. Folia Archaeologica 25, 2007, 267-283.

von Schnurbein 1977 - S. von Schnurbein: Das römische Gräberfeld von Regensburg. Text. Archäologische Forschungen in Regina Castra - Regensburg 1. Kallmünz 1977.

Schuster 2014 - J. Schuster: Dobór i układ darów w inhumacyjnych grobach książęcych z pierwszej połowy I tysiąclecia po Chr. w północnej i środkowej Europie. Wiadomości Archeologiczne 65, 2014, 5-44.

DOI: https://doi.org/10.36154/wa.65.2014.01

Steuer 2006 - H. Steuer: Fürstengräber, Adelsgräber, Elitegräber. Methodisches zur Anthropologie der Prunkgräber. In: C. von Carnap-Bornheim/D. Krausse/A. Wesse (Hrsg.): Herrschaft - Tod-Bestattung. Zu den vor-und frühgeschichtlichen Prunkgräbern als archäologisch-historische Quelle. Internationale Fachkonferenz Kiel 16.-19. Oktober 2003. Universitätsforschungen zur prähistorischen Archäologie 139. Bonn 2006, 11-25.

Symonds 2012 - R. P. Symonds: A brief history of the ceramic mortarium in antiquity. Journal of Roman Pottery Studies 15, 2012, 169-214.

Tejral 1999 - J. Tejral: Archäologisch-kulturelle Entwicklung im norddanubischen Raum am Ende der Spätkaiserzeit und am Anfang der Völkerwanderungszeit. In: J. Tejral/Ch. Pilet/M. Kazanski (éd.): L' Occident romain et l'Europe au début de lépoque des Grandes Migrations. Spisy Archeologického ústavu AV ČR Brno 13. Brno 1999, 205-271.

Tejral 2002 - J. Tejral: Region pod Pavlovskými vrchy v době stěhování národů. In: S. Stuchlík (ed.): Oblast vodního díla Nové Mlýny od pravěku do středověku. Brno 2002, 355-369.

Manuscript accepted 20. 4. 2021

Translated by author

dr hab. Judyta Rodzińska-Nowak, prof. UJ

Instytut Archeologii Uniwersytetu Jagiellońskiego

Gołębia 11

PL - 31-007 Kraków

rodzinska@interia.pl
Varsik 1998 - V. Varsik: Štruktúra germánských sídliskz 2.-3. storočia na juhozápadnom Slovensku (Branč a Vel'ký Meder). Dizertačná práca. Archeologický ústav SAV Nitra. Nitra 1998. Unpublished.

Varsik 2004 - V. Varsik: Zur Entwicklung der quadischen Siedlung von Vel'ký Meder (SW Slowakei). Študijné zvesti AÚ SAV 36, 2004, 257-275.

Winniczuk 1983 - L. Winniczuk: Ludzie, zwyczaje, obyczaje starożytnej Grecji i Rzymu. Warszawa 1983.

Witteyer 1993 - M. Witteyer: Die Ustrinen und Busta von Mainz-Weisenau. In: M. Struck (Hrsg.): Römerzeitliche Gräber als Quellen zu Religion, Bevölkerungsstruktur und Sozialgeschichte. Internationale Fachkonferenz vom 18.20. Februar 1991 im Institut für Vor-und Frühgeschichte der Johannes-Gutenberg-Universität Mainz. Archäologische Schriften des Instituts für Vor- und Frühgeschichte der Johannes-Gutenberg-Universität Mainz 3. Mainz 1993, 69-80.

Wunderlich 2002 - C.-H. Wunderlich: »Lightkultur«: Fettnäpchen, Tranfunzeln und Armleuchter. Vorgeschichtliche Beleuchtungstechnik in der Museumsnacht. Archäologie in Sachsen-Anhalt NF 1, 2002, 83-94.

Zeman 2006 - T. Zeman: Sídliště z pozdní doby římské ve Zlechově. Stav zpracování, východiska a cíle projektu. In: E. Droberjar/M. Lutovský (eds.): Archeologie Barbarů 2005. Sborník príspěvkü z I. protohistorické konference "Pozdně keltské, germánské a časně slovanské osídleni" (Kounice, 20.-22.záři 2005). Praha 2006, 451-469.

Zeman 2008 - T. Zeman: Zlechov. Sídliště ze závěru doby řimské a počáteční fáze stěhování národi̊ a jeho postaveni v rámci pozdního svébského osídlení Moravy. Dizertační práce. Masarykova univerzita. Filozofická fakulta. Brno 2008. Online available at: https://theses.cz/id/27dhez/ 
